DOI: $10.1515 / \mathrm{sjdv}-2017-0018$

\title{
Lues Maligna as an Initial Presentation of Underlying HIV Infection in a Homosexual Man
}

\author{
Milan BJEKIĆ \\ City Institute for Skin and Venereal Diseases, Belgrade \\ *Correspondence: Milan Bjekić, City Institute for Skin and Venereal Diseases, \\ Džordža Vašingtona 17, Belgrade 11000, Serbia, E-mail address: milinkovski@gmail.com \\ UDC [616.5-002.6:616.972]:[616.988:578.828]
}

\begin{abstract}
Lues maligna is a rare ulcerative form of secondary syphilis. This clinical entity is predominantly found in patients living with HIV or AIDS. We report a case of a 32-year-old homosexual man with diffuse non-pruritic, papular skin lesions, ulcerated nodules and plaques disseminated on the face, trunk and extremities. The rash was followed by fever, malaise and joint pains. Serological tests for syphilis were positive. The patient was treated with intramuscular penicillin and the lesions resolved completely. Lues maligna was an initial presentation of underlying HIV infection. The HIV seropositivity was confirmed by Western blot analysis. Due to the increased number of syphilis cases and frequent HIV co-infection in Serbia, dermatologists must be able to recognize this condition based on clinical characteristics and risk factors and to diagnose and treat it promptly.
\end{abstract}

Key words: Syphilis, Cutaneous; HIV Infections; Immunocompetence; Risk Factors; Skin Ulcer; Homosexuality, Male; Case Reports

\section{Introduction}

Lues maligna or ulceronodular syphilis is a rare manifestation of secondary syphilis first described by Bazin in 1859 who applied this term based on the grotesque clinical features (1). In the late 1800s, Neisser and Haslund defined the clinical characteristics of this form of secondary syphilis and distinguished it from the necrotizing gummatous disease of tertiary syphilis $(2,3)$. In the period between 1900 and 1988 only fourteen cases were reported in the English-language literature (4). However, more cases of lues maligna have been described in people with HIV/AIDS since HIV pandemic started $(4,5,6)$.

We report a case of lues maligna mimicking Pityriasis lichenoides et varioliformis acuta in a homosexual man. This was the first clinical manifestation revealing a hidden HIV infection.

\section{Case Report}

A 32-year-old homosexual man was referred to the Department of Sexually Transmitted Infections for the evaluation of a non-pru- ritic skin rash. The rash, which had appeared on his face one month earlier and spread to his entire body in the next two weeks, was followed by fever, malaise and joint pains. During the second week of the rash he visited a dermatologist at a walk-in clinic, where he was diagnosed with Pityriasis lichenoides et varioliformis acuta and an oral antibiotic (ciprofloxacine) was prescribed for two weeks. There was no improvement and the patient was referred to the City Institute for Skin and Venereal Diseases.

Physical examination revealed multiple erythematous papules, nodules and oval necrotic ulcerated plaques on the face, trunk and extremities (Figure 1 and 2). Ulcerations were covered with laminated, brown-black rupioid crusts (Figure 3 and 4). His palms and soles, genital area and oral mucosa were unaffected. There were no generalized lymphadenopathies. His personal history showed that he had had five sexual partners in the previous six months. He used a condom only during anal intercourse and practiced unprotected oral-genital and oral-anal sex. It was also found that the patient had had an asymptomatic anal lesion, which 
had had appeared two months before skin rash onset but passed spontaneously.

Laboratory findings, including complete blood count and blood chemistry were within normal limits, except for a high sedimentation rate, being 80 . Serological tests were performed and Venereal Disease Research Laboratory (VDRL) test was positive with titers 1:512 and Treponema Pallidum Hemagglutination Assay (TPHA) test was positive as well. The patient was treated with three consecutive doses of benzathine penicillin G, 2.4 million units intramuscularly at 1-week intervals (total 7.2 million units). A severe Jarish-Herxheimer reaction occurred in our patient. He developed chills, fever and sweating ten hours after the first application of penicillin. He took antipyretics and reaction resolved within 24 hours. Syphilitic lesion healing was fast and serology showed eight-fold decline of VDRL titre (it fell to 1:64) after three months of the treatment. The patient was counselled and tested for HIV. The HIV seropositivity was confirmed by the Western blot analysis.

\section{Discussion}

A worldwide syphilis incidence increase was recorded at the beginning of the new millennium, occurring primarily among men who have sex with men - MSM (7). An upsurge of syphilis incidence in Belgrade began in 2010 (8). During the period from 2010 to 2016, the incidence of syphilis increased in Belgrade by $227.5 \%$, from 2.25 per 100,000 in 2010 to 5.12 per 100,000 in 2016 (9). Men accounted for the most cases of syphilis during an early syphilis outbreak in 2014 , with the vast majority of such cases $(85.1 \%)$ occurring among homosexual men. One third of syphilis cases (all MSM) were co-infected with HIV (10). Patton et al (11) reported the rates of $50-70 \%$ of HIV co-infection among MSM infected with primary or secondary syphilis. However, HIV positive patients are presented more often with secondary syphilis and the disease course is more aggressive (12).

Known as the great imitator especially at the secondary stage, syphilis may present itself with a myriad of diverse morphological entities and clinical manifestations $(13,14)$ which emphasizes the importance of dermatological education of non-experienced physi-

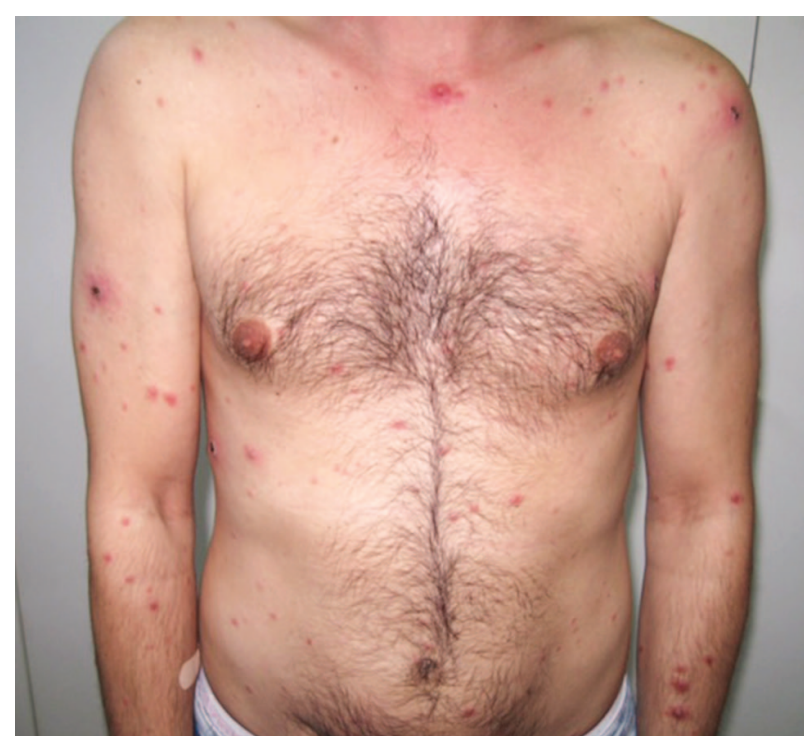

Figure 1. Disseminated papules, nodules and some ulcerated lesions on the trunk and extremities

cians, particularly under the current circumstances of syphilis resurgence in Serbia.

Lues maligna is a rare ulcerative form of secondary syphilis characterized by papulopustular skin lesions that rapidly enlarge and evolve into round or oval ulcers with sharp borders, centrally covered by a dark, sometimes rupioid crust (as described in our patient) while mucosal surfaces may also be affected (15). The onset of the eruption can be preceded by fevers, chills, anorexia, weight loss and severe headaches.

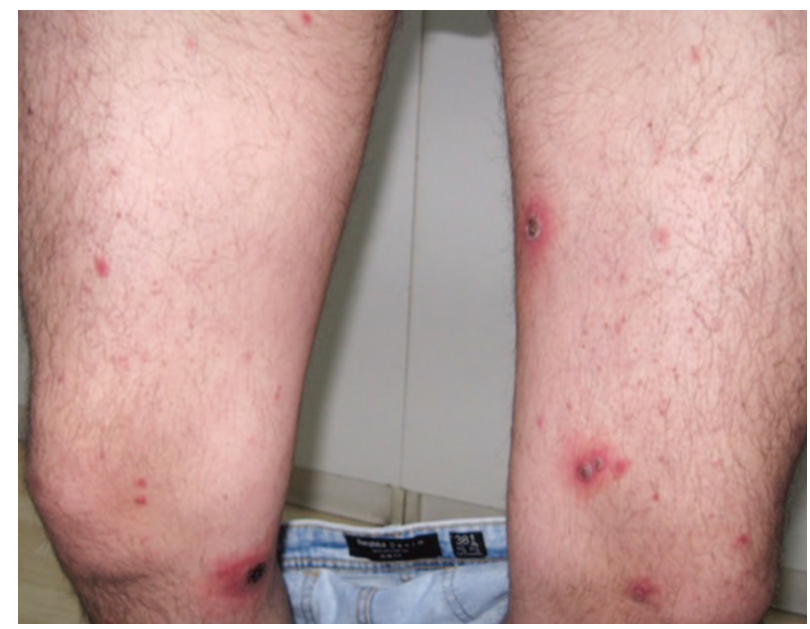

Figure 2. Erythematous papules and ulcerated lesions on the lower limbs 


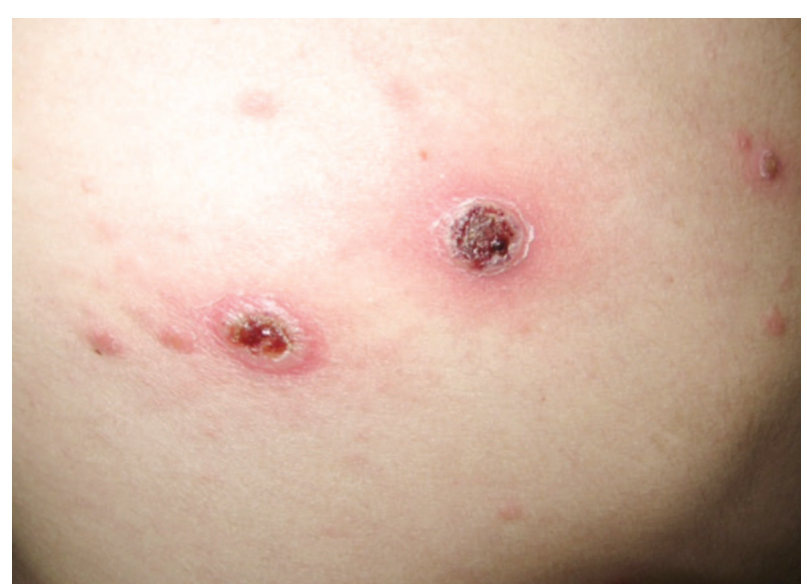

Figure 3. Characteristic ulcerations of lues maligna covered with crusts

Clinical conditions that mimic lues maligna include ecthyma, ecthyma gangrenosum, anthrax, blastomycosis-like pyoderma, pyoderma gangrenosum, atypical mycobacterial infection, deep fungal infection and vasculitis (16). Our patient was misdiagnosed as pityriasis lichenoides et varioliformis acuta.

The criteria for diagnosis of lues maligna listed by Fischer et al. (15) include compatible gross morphology, a high titre serologic test for syphilis, a severe Jarisch-Herxheimer reaction and an excellent response to antibiotic therapy. All of these manifestations were present in our patient.

The Jarisch-Herxheimer reaction is a transient immunological phenomenon seen commonly in patients during treatment of sec-

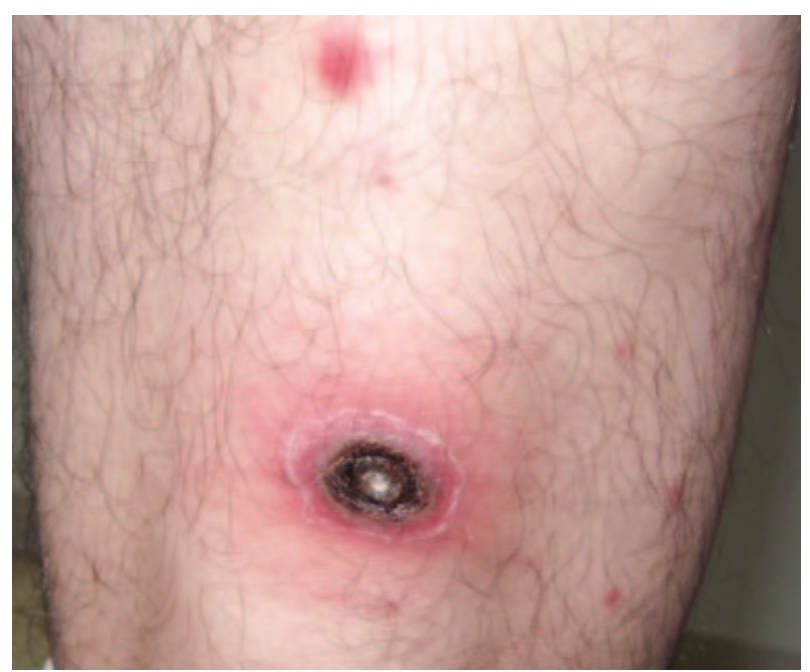

Figure 4. Rupioid crust on the popliteal fossa ondary syphilis. An increase in the incidence of this reaction has been described in the patients with lues maligna and in HIV infected patients (17). It is manifested with constitutional symptoms such as fever, headache, myalgia, chills and rigours which resolve within 24 hours. Corticosteroids have been used to offset the reaction with no conclusive evidence of their benefit (18).

Lues maligna was described well before the HIV pandemic and it was associated with severe malnutrition, alcoholism, diabetes mellitus and intravenous drug use (19-21). Following the HIV/AIDS epidemic, the incidence of lues maligna significantly increased; moreover, the patients with HIV were 60 times more likely to present with this form of syphilis (22). At present, it is estimated that up to $7 \%$ of syphilis cases found in HIV/AIDS patients meet the criteria for lues maligna (22), and they are frequently the first clinical manifestation revealing a hidden HIV infection, as we described in our patient.

\section{Conclusion}

Because of the increased number of syphilis cases and frequent HIV co-infection in Serbia, dermatologists should be wellaware of the possibility of occurrence of lues maligna cases. It is important to recognize and diagnose malignant syphilis early and introduce the appropriate treatment as the complete recovery can be achieved.

\section{Acknowledgement}

This work was supported by the Ministry for Science and Technology of Serbia, through Contract No. 175042 (2011-2014).

\section{References}

1. Bazin APE. Leçon Theorique et Cliniquas sur les Syphilides Rediquées par le Fournier. Paris: Adrian Delahayer; 1859.

2. Neisser A. Malignant syphilis. $\mathrm{Br} J$ Dermatol. 1897;9:11-26.

3. Haslund A. Syphilis maligna. Arch Dermatol Syph. 1897;38(1):345-92.

4. Shulkin D, Tripoli L, Abell E. Lue with human immunodeficiency virus infection. Am J Med. 1988;85(3):425-7.

5. Mohan GC, Ali RA, Isache CL, Sharma RK, Prniciaro C. Malignant syphilis: ostacerous, ulceronecrotic le- 
sions in a patient with human immunodeficiency virus. Dermatol Online J 2017 Jan 15; 23 (1)

6. Tucker JD, Shah S, Jarell AD, Tsai KY, Zembowicz A, Kroshinsky D. Lues maligna in early HIV infection case report and review of the literature. Sex Transm Dis. 2009;36(8):512-4.

7. Savage EJ, Hughes G, Ison C, Lowndes CM; European Surveillance of Sexually Transmitted Infections network. Syphilis and gonorrhoea in men who have sex with men: a European overview. Euro Surveill. 2009;14(47):pii: 19417.

8. Bjekić M, Šipetić S. An outbreak of early syphilis in patients registered at City Institute for Skin and Venereal Diseases in Belgrade from 2010 to 2012: a case series of 86 patients. Serbian Journal of Dermatology and Venereology. 2013;5(2):65-71.

9. Institute of Public Health of Serbia "Dr Milan Jovanovic Batut". Center for Disease Control and Prevention. Report of infectious diseases in the Republic of Serbia in 2016. Belgrade: Institute of Public Health of Serbia "Dr Milan Jovanovic Batut"; 2017. p. 62-73.

10. Bjekić M, Šipetić-Grujičić S, Begović-Vuksanović B, Rafailović N, Vlajinac H. Syphilis resurgence in Belgrade, Serbia in the new millennium - an outbreak in 2014. Cent Eur J Public Health. 2017;25(4):277-81.

11. Patton ME, Su JR, Nelson R, Weinstock H; Centers for Disease Control and Prevention (CDC). Primary and secondary syphilis - United States, 2005-2013. MMWR Morb Mortal Wkly Rep. 2014;63(18):402-6.

12. Lynn WA, Lightman S. Syphilis and HIV: a dangerou combination. Lancet Infect Dis. 2004;4(7):456-66.

13. Baughn RE, Musher DM. Secondary syphilitic lesions. Clin Microbiol Rev. 2005;18(1):205-16.
14. Bjekić M. Secondary syphilis in patients treated at the City Institute for Skin and Venereal Diseases in Belgrade from 2010 to 2014. Serbian Journal of Dermatology and Venereology. 2015;7(2):53-60.

15. Fisher DA, Chang LW, Tuffanelli DL. Lues maligna: presentation of a case and a review of the literature. Arch Dermatol. 1969;99(1):70-3.

16. Balagula Y, Mattei PL, Wisco OJ, Erdag G, Chien AL. The great imitator revisited: the spectrum of atypical cutaneous manifestations of secondary syphilis. Int J Dermatol. 2014;53(12):1434-41.

17. Yang CJ, Lee NY, Lin YH, Lee HC, Ko WC, Liao CH, et al. Jarisch-Herxheimer reaction after penicillin therapy among patients with syphilis in the era of the HIV infection epidemic: incidence and risk factors. Clin Infect Dis. 2010;51(8):976-9.

18. Belum GR, Belum VR, Chaitanya Arudra SK, Reddy BS. The Jarisch-Herxheimer reaction: revisited. Travel Med Infect Dis. 2013;11(4):231-7.

19. Lejman K, Starzycki Z. Syphilis maligna praecox. A case report. $\mathrm{Br} J$ Vener Dis. 1972;48(3):194-9.

20. Bayramgürler D, Bilen N, Yildiz K, Sikar A, Yavuz M. Lues maligna in a chronic alcoholic patient. J Dermatol. 2005;32(3):217-9.

21. Hofmann UB, Hund M, Bröcker EB, Hamm H. "Lues maligna" in a female patient with diabetes. J Dtsch Dermatol Ges. 2005;3(10):780-2.

22. Schöfer $H$, Imhof $M$, Thoma-Graber E, Brockmeyer $\mathrm{NH}$, Hartmann M, Gerken G, et al. Active syphilis in HIV infection: a multicentre retrospective survey. The German AIDS Study Group (GASG). Genitourin Med. 1996;72(3):176-81.

\section{Maligna forma sifilisa kao inicijalna prezentacija postojeće HIV infekcije kod homoseksualnog muškarca}

\section{Sažetak \\ Lues maligna je retka ulcerativna forma sekundarnog sifilisa koja se najčešće opisuje kod imunodeficijentnih pacijenata koji žive sa HIV-om. Prikazujemo muškarca homoseksualne orijentacije, starog 32 godine, koji se javio lekaru zbog difuznih nepruriginoznih promena u vidu papula, ulcerisanih nodusa i plakova lokalizovanih na licu, trupu i ekstremitetima. Osip po koži je bio praćen groznicom, malaksalošću i bolovima u zglobovima. Serološki testovi za sifilis bili su pozitivni i pacijent je}

lečen intramuskularno penicilinom te su se sve promene na koži povukle. S obzirom na to da se maligna forma sifilisa češće javlja kod osoba inficiranih HIV-om, pacijent je upućen na testiranje i seropozitivnost je potvrđena Vestern blot testom. Usled povećane incidencije sifilisa u Srbiji i česte udruženosti ove infekcije sa HIV-om, dermatolozi bi morali da na osnovu karakteristične kliničke slike i faktora rizika posumnjaju, dijagnostikuju i leče ovu retku formu sekundarnog sifilisa.

Ključne reči: Kutani sifilis; HIV infekcije; Imunokompetencija; Faktori rizika; Ulceracije kože; Homoseksualnost kod muškaraca; Prikazi slučajeva 